\title{
Hyporheic biofilm development on artificial substrata, as a tool for assessing trophic status of aquatic systems : first results
}

\author{
C. Claret $^{1}$
}

Keywords : interstitial water, DOC, bacterial counts, ETS-active bacteria.

To determine the relationship between biofilm characteristics and organic nutrient content, we investigated the development of hyporheic biofilms on artificial substrata (glass slides) in the early phase of bacterial colonization (one week) in contrasting river habitats with significantly different concentrations of dissolved organic carbon (DOC) and biodegradable and refractory DOC (BDOC and RDOC). Results suggest that the quality of DOC (i.e. BDOC versus RDOC content) controlled electron -transport system (ETS)-active bacterial abundances early in colonization, while DOC concentrations limit biofilm development only in the latter phase of colonization.

Le développement de biofilms hyporhéiques sur des substrats artificiels, un outil d'évaluation du niveau trophique des systèmes aquatiques : premiers résultats

Mots clés : eau interstitielle, COD, dénombrements bactériens, bactéries à STE actif.

Afin de mettre en évidence les relations entre les caractéristiques des biofilms et les concentrations en nutriments organiques du milieu, nous avons suivi la croissance de biofilms hyporhéiques sur des substrats artificiels (lames de verre) durant les premiers stades de colonisation ( 1 semaine) dans deux habitats aquatiques où les concentrations en carbone organique dissous (COD) et en COD réfractaire et biodégradable (CODR et CODB) sont significativement différentes. Les résultats laissent supposer que la qualité du DOC (i.e. CODB et CODR) exercerait un contrôle sur les bactéries à système de transport d'électrons (STE) actif dès les premiers stades de colonisation, alors que lès concentrations en COD ne deviendraient quantitativement limitantes que pour des biofilms bien développés.

\section{Introduction}

Biofilms are mixed assemblages of bacteria, fungi, and algae that develop on all surfaces in contact with water (Trulear \& Characklis 1982, Lock et al. 1984, Characklis \& Marshall 1990). As they grow, microbial organisms secrete a polysaccharide matrix, the glycocalyx. This matrix displays adsorption and diffusion properties that favour the retention of dissolved organic matter from the water column (Mickelburg et al. 1984, Jones \& Lock 1989, Fiebig \& Lock 1991, Fiebig 1992, Flemming 1995, Freeman et al. 1995). Thus, biofilms play a major role in biogeochemical processes such as nutrient cycling (Liu et al. 1993). Bacteria are

\footnotetext{
1. Université de Savoie, GRETI (et ESA-CNRS 5023,
} Villeurbanne), F - 73376 Le Bourget du Lac, France. the main biofilm component that able to take up dissolved organic molecules from the water column (Sepers 1977, Thurman 1985). Unfortunately, the relationship between heterotrophic bacteria and organic nutrients is often difficult to understand because organic nutrients support biofilm growth, and in turn, biofilms produce nutrients during organic matter mineralization.

In streambed sediments where light is not available, hyporheic biofilm development is largely supported by organic matter from the surface because autochthonous chemolithotrophic production is often low and photosynthetic primary production is non-existent (Gantzer et al. 1988, Gibert et al. 1994). The absence of interactions between algae and bacteria in interstitial biofilms should allow direct exploration of relationships between biofilm development and quantities 
of available nutrients. However, heterogeneity of natural substrata induces heterogeneous biofilm development, confounding research efforts (Claret \& Fontvieille 1997). Artificial subtrata simplify environmental conditions by providing a surface with homogeneous texture and size for biofilm growth over a fixed colonization time (Cattaneo \& Amireault 1992) ; they have been used in many surface water studies to estimate periphyton biomass at steady-state (e.g. Sladeckova 1962, Biggs 1985, Watanabe et al. 1988, Aloi 1990, Cattaneo \& Amireault 1992, Findlay et al. 1993, Liu et al. 1993), but rarely to study biofilm development in interstitial environments (Bärlocher \& Murdoch 1989).

The aim of this study is (i) to describe the dynamics of biofilm development on artificial substrata in the early phase of bacterial colonization, and (ii) to determine whether relationships exist between biofilm characteristics and organic nutrient content in two contras- ting river habitats (i.e. an active channel and a backwater system of the Rhône River).

\section{Study sites}

The first study site (site 1, Fig. 1) is a drainage canal located in the Brégnier-Cordon sector (about 90-100 $\mathrm{km}$ upstream from Lyon) of the French Upper Rhône River . This drainage canal, situated on the west side of the Rhône River, has been artificially hollowed to collect water which infiltrates from the headrace canal. It is supplied mostly by interstitial and phreatic waters from a serie of springs that well up through the sides and bed of the channel. Two locations were chosen at site 1 , one at the upstream part of the canal in an upwelling zone (location B) where interstitial water enters the surface, and one located at the downstream part of the canal in a downwelling zone (location A), where surface water infiltrates into the sediments. Three pipes were inserted $50 \mathrm{~cm}$ below the sediment surface
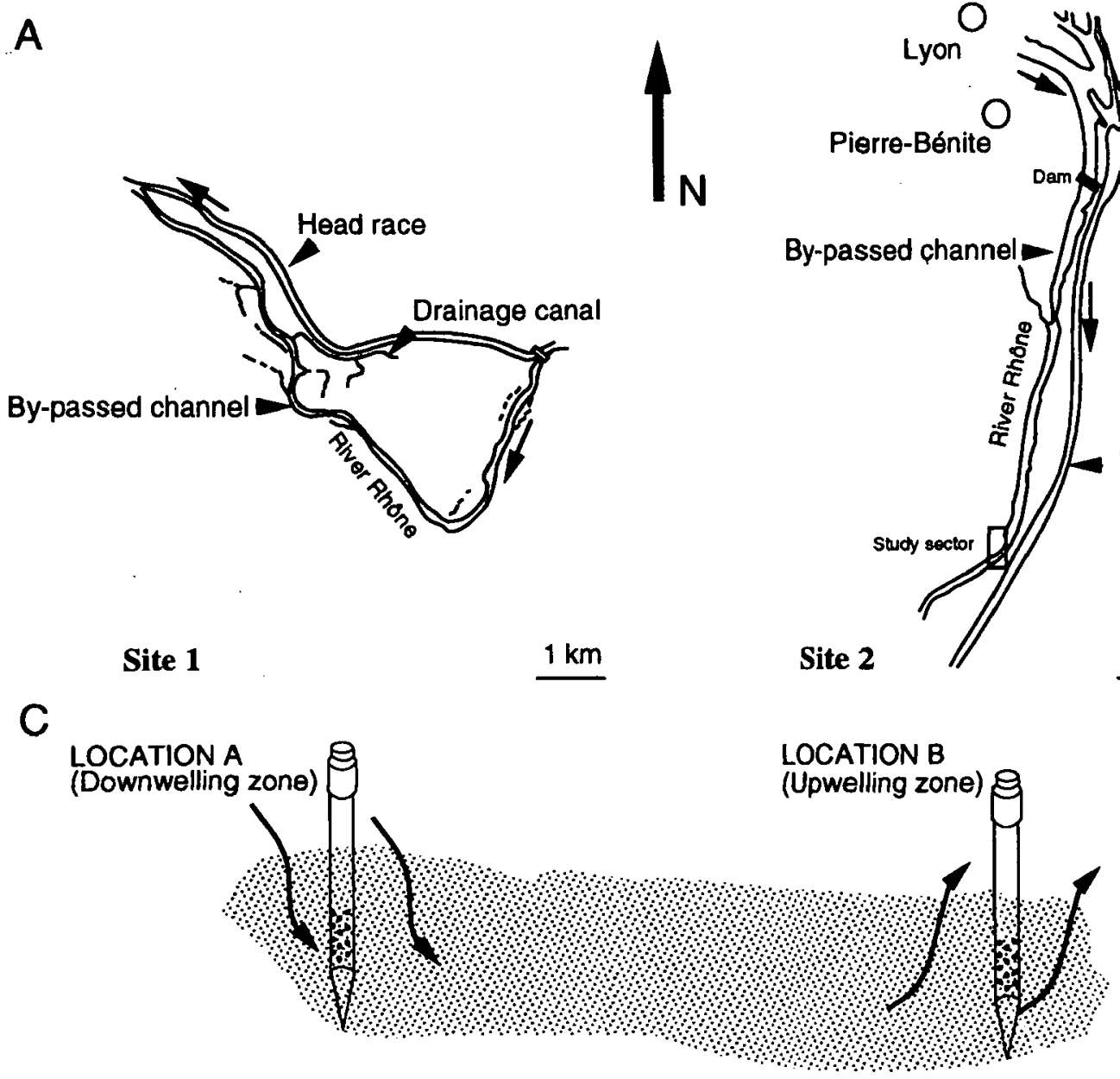
Interstitial sediments
Water flow directional

B

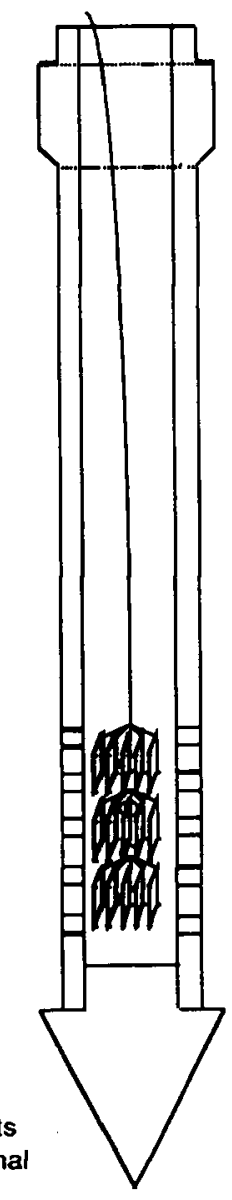

Fig. 1. A - Location of the Brégnier-Cordon (site 1) and the Pierre-Bénite sectors (site 2) were the study took place. B - Schematic representation of the device used for hyporheic biofilm development monitoring. $C$ - Diagram of the pipe settling in the two locations (A for downwelling zone and B for upwelling zone).

Fig. 1. A - Localisation des secteurs d'étude : Brégnier-Cordon (site 1) et Pierre-Bénite (site 2). B - Représentation schématique du système utilisé pour suivre le développement des biofilms hyporhéiques. C - Représentation des sondes installées en position A (zone d'infiltration d'eau de surface) et en position B (zone de restitution d'eau interstitielle). 
at each location during two successive study periods in April and May 1995.

The second study site (site 2 ) is an active channel located downstream from the city of Lyon in the PierreBénite sector. This channel is part of a bypassed section of the Rhône River downstream from the PierreBénite dam (Fig. 1), one of several hydroelectric facilities of this type on the Rhône. The scheme consists of a retention canal (or reservoir), a headrace, a tailrace, and a bypass section which acts as an outlet during periods of elevated flow. Discharge in the bypass section is regulated at $10 \mathrm{~m}^{3} \mathrm{~s}^{-1}$ from September to March, and $20 \mathrm{~m}^{3} \mathrm{~s}^{-1}$ from April to August. We established two locations ( $150 \mathrm{~m}$ from each other) in a riffle $4.4 \mathrm{~km}$ downstream from the dam: one located at the upstream end of the riffle, where surface water infiltrates into the sediments (location A, a downwelling zone) and the other downstream of the riffle, where interstitial water enters the surface (location B, an upwelling zone). Three pipes were inserted $50 \mathrm{~cm}$ below the sediment surface at each location during two successive study periods in October and November 1994.

\section{Material and methods}

\subsection{Apparatus and artificial substrata settling}

Artificial substrata were suspended in a stainless-steel pipe ( $50 \mathrm{~mm}$ outer diameter, $33 \mathrm{~mm}$ inner diameter) perforated with 9 rows of $5 \mathrm{~mm}$ diameter holes $20 \mathrm{~mm}$ from the distal end (Fig. 1). The pipe was hammered into the sediment, and artificial substrata were then introduced into the pipe which was covered with a cap to avoid surface water input. Artificial substrata were composed of 12 acid washed, pre-combusted $\left(550^{\circ} \mathrm{C}\right.$ for one hour) glass slides $(76 \times 25 \mathrm{~mm})$ with one sanded side threaded onto nylon line and hung vertically in the pipe. Slides were held at $0.5 \mathrm{~cm}$ from the bottom of the pipe in front of the perforations (Claret 1998).

\subsection{Water analysis}

Downwelling and upwelling zones were located using the hydraulic gradient method (Freeze \& Cherry 1979). Pressure differences between surface water and interstitial water were measured using a manometer. Temperature, specific conductance, and oxygen were measured in situ with a thermoconductimeter (WTW LF 92) and a dissolved oxygen meter (WTW OXI 92).

Interstitial water was collected and stored in $500 \mathrm{ml}$ prewashed polyethylene bottles using a peristaltic pump (Willy A. Bachofen). The bottles were kept in an ice chest during the 30 minutes required to return to the laboratory. DOC was measured with a Dohrman DC80 'Total Carbon Analyser' based on UV-promoted potassium persulfate oxidation (precision $\pm 1 \%$ ) after removing mineral carbon using orthophosphoric acid $(1 \mu \mathrm{l} / \mathrm{ml})$ and $\mathrm{CO} 2$ stripping under a $10 \mathrm{~min}$ oxygen flow. Biodegradable (BDOC), the part of DOC assi- milated by autochtonous heterotrophic bacteria during a short incubation time ( $<4$ weeks), and refractory (RDOC) fractions of dissolved organic carbon were assessed according to the method of Servais et al. $(1987,1989)$. A $0.2 \mu \mathrm{m}$ cellulose acetate membrane was washed 3 times with $20 \mathrm{ml}$ of organic-C free distilled water and then used to filter 130 $\mathrm{ml}$ of the sample. Ten $\mathrm{ml}$ were kept for the initial DOC measurement. The remaining $120 \mathrm{ml}$ were transferred into precombusted $\left(550^{\circ} \mathrm{C}, 4 \mathrm{~h}\right)$ glass bottles fitted with aluminium stoppers. Bottles were then inoculated with a $1 \mathrm{ml}$ suspension of autochtonous bacteria (collected from the acetate filter) and incubated in the dark for 25 and 30 days at $15^{\circ} \mathrm{C}$ after which time aliquots were removed for DOC determination. BDOC was calculated as the difference between initial and final DOC, and RDOC equalled the final DOC concentration. DOC concentration decreased within two days then stabilized until the end of the incubation (Servais et al. 1989, Boissier \& Fontvieille 1992). Measurements at 25 and 30 days always gave similar values of RDOC. Percent BDOC and $R D O C$ were calculated from the BDOC/DOC ratio and the RDOC/DOC ratio, respectively.

\subsection{Microbial variables}

Artificial substrata were put into $100 \mathrm{ml}$ of demineralized, filtered $(0.2 \mu \mathrm{m})$ water and fixed with $1 \mathrm{ml}$ of formaldehyde (final concentration $3.7 \%$ ) for determination of total bacterial abundance. Glass slides were sonicated for 180 seconds at power 2 and $50 \%$ duty cycle to remove bacteria (sonication conditions which remove the greatest number of bacteria from this type of support ; Claret 1998). Twenty $\mathrm{ml}$ of this suspension were filtered on a GTBP millipore membrane $(0.2 \mu \mathrm{m})$ and bacteria were stained with a $10 \mu \mathrm{g} \mathrm{ml}^{-1} 4^{\prime}, 6$-diamidino-2-phenylindole (DAPI) solution for 10 minutes at room temperature. The membrane was then washed and mounted with a non-fluorescent immersion oil (Zeiss $518 \mathrm{C}$ ) on a microscope slide (Porter \& Feig 1980, Fry 1988). A minimum of 400 bacteria were counted, under an epifluorescence microscope (Olympus BH-2, fitted with a $200 \mathrm{~W}$ mercury burner and an Olympus UG-1 $365 \mathrm{~nm}$ excitation filter). The number of ETS-active bacteria was measured using 5cyano-2,3-ditolyl tetrazolium chloride (CTC) staining (Rodriguez et al. 1992, Schaule et al. 1993; Yu \& McFeters 1994). Sample processing for CTC was similar to the one used for DAPI staining ; total bacterial abundance and ETSactive bacterial abundance can be directly compared and percent active bacteria as CTC/DAPI ratio can be calculated. Artificial substrata were incubated in a $13.8 \mathrm{mg} \mathrm{ml}^{-1}$ CTC (that be equivalent to $4.7 \mathrm{mM}$ final concentration) solution for 3 hours in the dark at $20^{\circ} \mathrm{C}$. They were then put into $100 \mathrm{ml}$ of demineralized, filtered $(0.2 \mu \mathrm{m})$ water with $1 \mathrm{ml}$ of formaldehyde. Slides were sonicated after the incubation and $50 \mathrm{ml}$ of suspension was filtered so as to obtain appropriate densities per microscope field. Bacteria were counted under epifluorescence microscope (Olympus BH-2) fitted with a 200W mercury, a blue filter (Olympus model BP 490) and a $590 \mathrm{~nm}$ barrier filter (Olympus model 0590). 


\subsection{Sampling strategy}

Biofilm colonization was monitored by measuring total bacterial abundance and percent active bacteria over increasing time periods: 3,5 , and 7 days after introducing slides into the pipe (that correspond to day 0 ). Temperature, dissolved oxygen, and DOC, BDOC, and RDOC were measured in situ on day 3,5, and 7. All parameters were measured in triplicates.

\subsection{Statistical analysis}

Statistical analyses were performed using the Statistica/W (ver. 5) statistical package (StatSoft Inc., Tulsa, USA). Spatial differences within and between study sites were examined using a Kruskal-Wallis non-parametric test (KW test, ANOVA on ranks) for temperature, dissolved oxygen, and organic nutrients (DOC, BDOC, RDOC) as well as for biofilm growth on days 3,5, and 7 in terms of total bacteria, ETS-active bacteria, and percent ETS-active bacteria. This non-parametric test was chosen because of the heterogeneity of variance among most variables. Pearson's correlation coefficients were calculated for ETS-active bacterial abundances and percent versus DOC, BDOC, RDOC and percent $B D O C$ and RDOC. Bacterial data were log-transformed $(y=\log [x])$ to meet the normality requirements of Pearson's correlations. Correlations were calculated using data from day 3 (between biofilm characteristics and organic nutrient concentrations after 3 day exposure time) and day 7 (between biofilm characteristics after 7 day exposure time and means of day 3 , day 5 and day 7 organic nutrient concentrations).

\section{Results}

Temperature was not significantly different between the three exposure times (Table $1 ; \mathrm{KW}$ test, $\mathrm{p}>0.05$ ) nor between the two study sites, whatever the location (Table 2). At each site, a significantly lower temperature was measured in the downwelling zone, location A than in the upwelling zone, location B (Table 2). Oxygen content of interstitial water did not significantly varied with the three exposure times, whatever sites and locations (Table $1 ; \mathrm{KW}$ test, $\mathrm{p}>0.05$ ). Interstitial water was always well oxygenated, although there was significantly less dissolved oxygen at site 1 than at site 2 . At site 2, dissolved oxygen content was significantly lower at location B than at location A (Table 2). At both stations, DOC content significantly decreased with exposure time at location A only (Table $1 ; \mathrm{KW}$ test, $\mathrm{p}$ $<0.05$ ). In the same way, BDOC content decreased from day 3 to day 7 but differences was significant at location $\mathrm{A}$ in site 2 only (KW test, $\mathrm{p}<0.05$ ). RDOC content also decreased with time at location $\mathrm{A}$ but at site 1 only ; in contrast, highest values were measured on day 5 at location $B$ in site 1 and at location $A$ in site 2 (KW test, $\mathrm{p}<0.01$ ). Site 2 displayed significantly higher DOC, BDOC, RDOC contents, and percent
BDOC than at site 1 , while the reverse pattern was observed for percent RDOC (Table 2). At site 1, there was significantly more DOC and RDOC contents in the downwelling zone, location $\mathrm{A}$ than in upwelling zone, location B (Table 2). Thus, percent RDOC was significantly higher and, inversely, percent BDOC was significantly lower in location A than in location B (Table2). The same pattern was observed at site 2 (Table 2).

At both sites, the number of total bacteria increased by a factor of 1.5 between day 3 and day 7 (Fig. 2). At site 1 , total bacterial abundances differed significantly among the three exposure times (KW test, $\mathrm{p}<0.05)$; highest bacterial number was counted after 7 days of exposure at location A $\left(1.310^{5} \pm 0.110^{5}\right.$ cells $\left.\mathrm{cm}^{-2}\right)$, while highest values occurred on day 5 at location $B$ $\left(1.510^{5} \pm 0.210^{5}\right.$ cells cm$^{-2}$; Fig. 2). Slight spatial differences were observed, as significantly more bacteria were present at location B than at location A on day 5 and day 7 (KW test, $\mathrm{p}<0.01$ ). At site 2, patterns of bacterial colonization were similar between locations A and B (Fig. 2). Abundances increased significantly on each subsequent exposure time (KW test, $\mathrm{p}<0.01$ ) and maximum number of total bacteria occurred on day 7 in both locations $\left(2.010^{5} \pm 0.310^{5}\right.$ cells $\mathrm{cm}^{-2}$ and $1.810^{5} \pm 0.310^{5}$ cells $\mathrm{cm}^{-2}$ at locations $\mathrm{A}$ and $\mathrm{B}$, respectively). However, there were significantly more bacteria in location A than in location B (KW test, $\mathrm{p}<$ $0.05)$.

At site 1, percent ETS-active bacteria decreased significantly from day $3(14 \% \pm 7 \%)$ to day $7(7 \%$ $\pm 1 \%$ ) at location B only (KW test, p $<0.01$; Fig. 2). This pattern was slightly different at location $\mathrm{A}$, where the highest percentage occurred on day $5(16 \% \pm 5 \%)$; this value was significantly higher at location $A$ than at location B (KW test, $\mathrm{p}<0.01$; Fig. 2). At site 2, a similar pattern was observed, with the highest percent ETS-active bacteria occurring after 3 days then decreasing on day 7 (Fig. 2). However, this decrease was significant at location B only (from $23 \pm 2 \%$ on day 3 to $10 \pm 6 \%$ on day 7 ; KW test, $\mathrm{p}<0.05$ ). Percent ETSactive bacteria were not significantly different between locations on any single sampling day at this site $(\mathrm{KW}$ test, $\mathrm{p}>0.05$ ).

Linear correlations were considered between organic nutrients content and biological variables for 3 day and 7 day exposure time. After day 3 (when maximum percent ETS-active bacteria were generally observed), total bacterial abundance was not significantly correlated with DOC (for both content and percent BDOC and RDOC), while after day 7 (when the highest total bacterial abundances were generally observed), a posi- 
Table 1. Pressure differences between surface water and interstitial water, water chemistry and nutrient concentrations (Dissolved Organic Carbon, DOC ; Biodegradable Dissolved Organic Carbon, BDOC ; Refractory Dissolved Organic Carbon, RDOC) of interstitial water sampled in inlet (A) and outlet (B) pipe on day 3, 5, and, 7 at each site and each location (mean $\pm \mathrm{SD} ; \mathrm{n}=18$ ).

Tableau 1. Différences de pression entre le milieu de surface et le milieu interstitiel, paramètres physiques et chimiques, concentrations en nutriments (Carbone Organique Dissous, COD ; Carbone Organique Dissous Biodégradable, CODB ; Carbone Organique Dissous Réfractaire, CODR) dans l'eau interstitielle échantillonnée dans les sondes au jour 3,5 et 7 dans la zone d'infiltration (A) et la zone d'exfiltration (B) dans chacun des sites (1 ou 2) (moyenne \pm écart-type ; $n=18$ ).

Site 1

Site 2

\begin{tabular}{|c|c|c|c|c|c|}
\hline & Day & A & B & A & B \\
\hline Pressure (mm) & & -4 & 18 to 24 & -40 to -50 & 140 \\
\hline \multirow{3}{*}{ Temperature $\left({ }^{\circ} \mathrm{C}\right)$} & 3 & $9.7 \pm 0.1$ & $11.2 \pm 1.0$ & $10.8 \pm 3.9$ & $13.4 \pm 2.7$ \\
\hline & 5 & $9.6 \pm 0.8$ & $11.6 \pm 0.6$ & $9.3 \pm 2.4$ & $13.1 \pm 3.0$ \\
\hline & 7 & $9.7 \pm 0.8$ & $11.6 \pm 0.4$ & $10.1 \pm 3.4$ & $13.2 \pm 2.7$ \\
\hline \multirow{3}{*}{ Dissolved oxygen (mg.1 $\left.1^{-1}\right)$} & 3 & $5.5 \pm 1.5$ & $6.7 \pm 1.7$ & $9.2 \pm 3.9$ & $7.9 \pm 2.8$ \\
\hline & 5 & $5.9 \pm 0.8$ & $6.2 \pm 1.0$ & $11.9 \pm 2.4$ & $8.4 \pm 1.8$ \\
\hline & 7 & $5.2 \pm 1.5$ & $5.7 \pm 0.9$ & $12.4 \pm 2.2$ & $8.3 \pm 0.4$ \\
\hline \multirow{3}{*}{$\mathrm{DOC}\left(\mathrm{mg} \cdot \mathrm{I}^{-1}\right)$} & 3 & $2.5 \pm 0.1$ & $1.3 \pm 0.1$ & $3.9 \pm 0.5$ & $3.6 \pm 1.4$ \\
\hline & 5 & $2.3 \pm 0.3$ & $1.5 \pm 0.3$ & $3.2 \pm 0.3$ & $2.5 \pm 0.3$ \\
\hline & 7 & $1.8 \pm 0.1$ & $1.4 \pm 0.1$ & $2.9 \pm 0.6$ & $2.8 \pm 0.2$ \\
\hline \multirow{3}{*}{ BDOC (mg. $\left.\mathrm{l}^{-1}\right)$. } & 3 & $0.7 \pm 0.1$ & $0.5 \pm 0.1$ & $1.9 \pm 0.6$ & $2.4 \pm 1.4$ \\
\hline & 5 & $0.6 \pm 0.4$ & $0.6 \pm 0.2$ & $0.9 \pm 0.04$ & $1.0 \pm 0.5$ \\
\hline & 7 & $0.6 \pm 0.1$ & $0.7 \pm 0.1$ & $0.9 \pm 0.7$ & $1.6 \pm 0.3$ \\
\hline \multirow{3}{*}{ RDOC (mg.l-1) } & 3 & $1.8 \pm 0.1$ & $0.8 \pm 0.04$ & $2.0 \pm 0.6$ & $1.2 \pm 0.02$ \\
\hline & 5 & $1.6 \pm 0.2$ & $0.9 \pm 0.1$ & $2.4 \pm 0.2$ & $1.3 \pm 0.1$ \\
\hline & 7 & $1.2 \pm 0.03$ & $0.7 \pm 0.02$ & $1.9 \pm 0.2$ & $1.2 \pm 0.1$ \\
\hline \multirow{3}{*}{$\operatorname{BDOC}(\%)$} & 3 & $27 \pm 2$ & $39 \pm 7$ & $43 \pm 8$ & $62 \pm 1.5$ \\
\hline & 5 & $26 \pm 1.6$ & $39 \pm 6$ & $27 \pm 1 . \dot{3}$ & $40 \pm 1.6$ \\
\hline & 7 & $32 \pm 2$ & $49 \pm 3$ & $28 \pm 2$ & $57 \pm 6$ \\
\hline \multirow{3}{*}{ RDOC (\%) } & 3 & $73 \pm 2$ & $61 \pm 7$ & $52 \pm 8$ & $38 \pm 1.5$ \\
\hline & 5 & $74 \pm 1.6$ & $61 \pm 6$ & $73 \pm 1$ & $60 \pm 1.6$ \\
\hline & 7 & $68 \pm 2$ & $51 \pm 3$ & $72 \pm 2$ & $43 \pm 6$ \\
\hline
\end{tabular}


Table 2. Kruskal-Wallis (ANOVA on ranks) summary of differences between sites (Brégnier-Cordon, site 1 and Pierre-Bénite, site 2) at each location and differences between locations (A and B) in each site for temperature and dissolved oxygen, $\mathrm{DOC}, \mathrm{BDOC}$ and $\mathrm{RDOC}$ concentrations, and $\mathrm{BDOC}$ and RDOC percent (see table 1 for abbreviations). $\mathrm{df}=1 ; \mathrm{n}=36 ;-$ : non significant ; $: \mathrm{p}<0.05 ;{ }^{* *}: \mathrm{p}<0.01$.

Tableau 2. Comparaison de rang (test de Kruskal-Wallis) des températures, des concentrations en oxygène dissous, des concentrations en COD, CODB, and CODR et des pourcentages de CODB et de CODR entre les sites (Brégnier-Cordon, site 1 et Pierre-Bénite, site 2) en zone d'infiltration et d'exfiltration et entre la zone d'infiltration et la zone d'exfiltration (A ou B) dans chaque site (voir tableau 1 pour la signification des abréviations). df $=1 ;-$ : non significatif ; $*$ : $<<0.05 ; * *: p<0.01$.

\begin{tabular}{|c|c|c|c|c|c|c|}
\hline & \multicolumn{3}{|c|}{$\begin{array}{l}\text { Differences between sites ( } 1 \text { and } 2 \text { ) at } \\
\text { each location }\end{array}$} & \multicolumn{3}{|c|}{$\begin{array}{l}\text { Differences between location (A and B) } \\
\text { at each site }\end{array}$} \\
\hline & & $\mathbf{H}$ & $\begin{array}{l}\text { site with } \\
\text { highest value }\end{array}$ & & H & $\begin{array}{l}\text { location with } \\
\text { highest value }\end{array}$ \\
\hline Temperature & Loc. A & - & - & site 1 & 23.5 ** & B \\
\hline$\left({ }^{\circ} \mathrm{C}\right)$ & Loc. B & - & - & site 2 & $7.4 * *$ & B \\
\hline Dissolved & Loc. A & $20.5 * *$ & 2 & site 1 & - & - \\
\hline oxygen (mg. $\mathrm{l}^{-1}$ ) & Loc. B & $11.6 * *$ & 2 & site 2 & $9.0^{* *}$ & A \\
\hline DOC & Loc. A & $18.5^{* *}$ & 2 & site 1 & $22.2 * *$ & A \\
\hline$\left(\mathrm{mg} \cdot \mathrm{l}^{-1}\right)$ & Loc. B & $26.3^{* *}$ & 2 & site 2 & $6.1^{* *}$ & A \\
\hline BDOC & Loc. A & $9.23^{* *}$ & 2 & site 1 & - & - \\
\hline$\left(\mathrm{mg} \cdot \mathrm{l}^{-1}\right)$ & Loc: $B$ & $17.7^{* *}$ & 2 & site 2 & - & - \\
\hline RDOC & Loc. A & $21.6 * *$ & 2 & site 1 & $26.3 * *$ & A \\
\hline (mg.1-1) & Loc. B & $26.0 * *$ & 2 & site 2 & $26.3^{* *}$ & $\mathbf{A}$ \\
\hline BDOC & Loc. A & - & - & site 1 & 17.4 ** & B \\
\hline$(\%)$ & Loc. B & $11.5 * *$ & 2 & site 2 & $9.0 * *$ & B \\
\hline RDOC & Loc. A & - & - & site 1 & $17.4 * *$ & A \\
\hline (\%) & Loc. B & $9.4^{* *}$ & 1 & site 2 & $11.0^{* *}$ & A \\
\hline
\end{tabular}

tive relationship existed between total bacterial abundance and both DOC and RDOC contents (Fig. 3). After 3 days of exposure, percent ETS-active bacteria were positively correlated with BDOC content and percent BDOC, and negatively correlated with percent RDOC (Fig. 3). No significant correlations were observed between percent ETS-active bacteria and DOC content on day 7 .

\section{Discussion}

At all sites and locations, temperature and dissolved oxygen content in the pipe allowed a rapid biofilm colonization of artificial substrata, with a similar pattern of development occurring at the two sites (site 1 and site 2). This temporal trend resembled to those described in other natural and laboratory settings (Kevern et al. 1966, Characklis et al. 1982, Belkhadir et al. 1988, Capdeville et al. 1988, Kuroda et al. 1988, Bakke et al. 

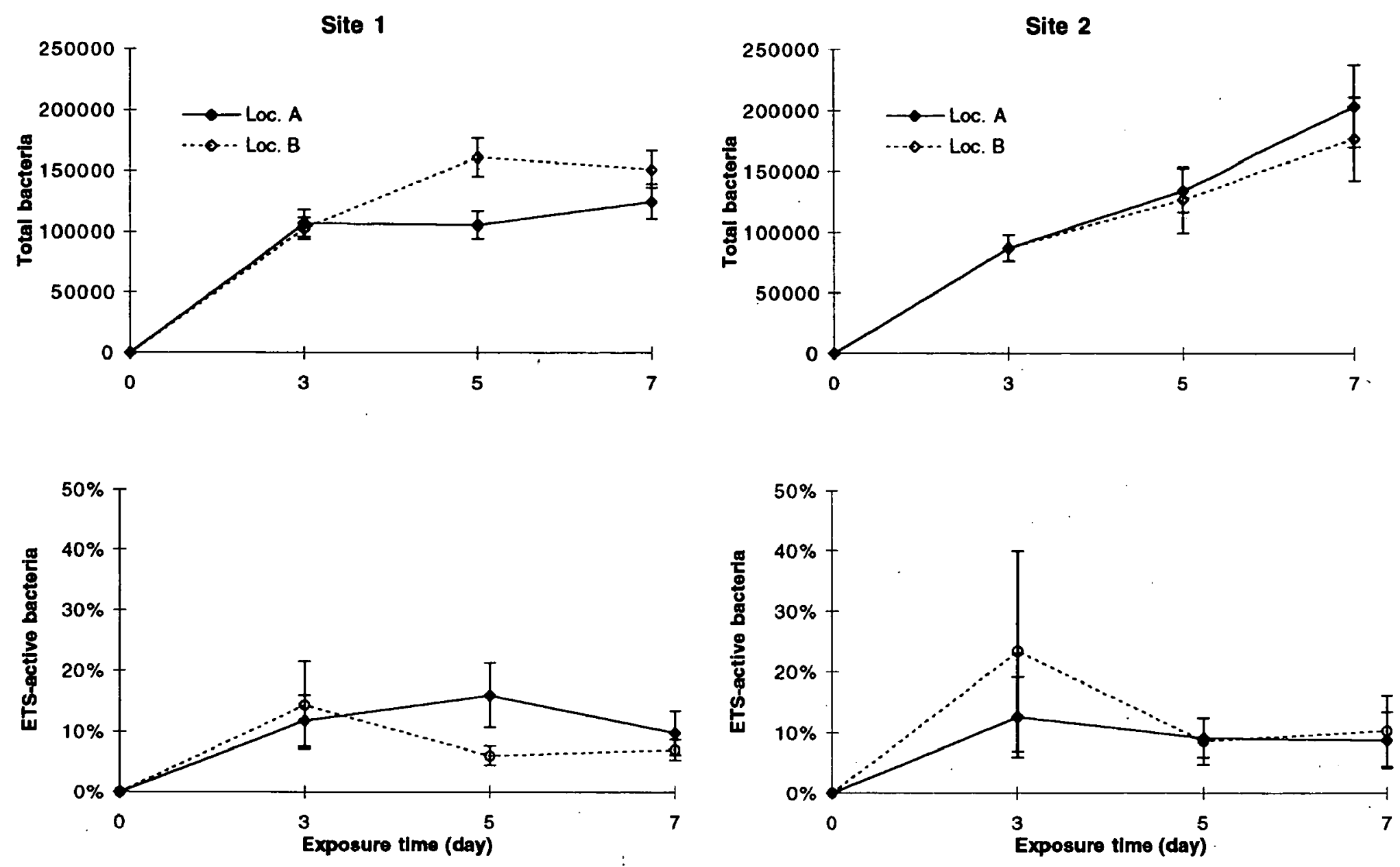

Fig. 2. Mean ( $\pm S D, n=6$ ) of total bacterial abundances and percent electron transport system (ETS)-active bacteria from day 0 to day 7 exposure time.

Fig. 2. Moyenne ( \pm écart-type, $\mathrm{n}=6$ ) des abondances totales de bactéries et du pourcentage de bactéries à système de transport d'électrons actif (STE) du jour 0 au jour 7 d'incubation dans le milieu naturel.

1990, Hoppe 1991). ETS-active abundances and percentages were greatest during the earliest period of biofilm colonization (day 3 ). Differences between total and ETS-active bacteria abundance were not surprising. Sabater \& Romani (1996) observed that ETS activity per unit area increased steeply within 4 days, but that ETS activity per cell decreased after 8 days of biofilm development in an undisturbed oligotrophic stream. Similar results were obtained for extracellular enzyme activity, with a peak after 2 days of colonization (Jones \& Lock 1989).

The temporal delay between maximum activity and maximum numbers observed at both sites may be linked to the first step of biofilm formation. Exopolysaccharide production associated with glycocalyx formation and bacterial multiplication occur during the initial establishment and growth of a biofilm and require high levels of bacterial activity. In the same way, Liu et al. (1993) showed that natural biofilms were derived mainly from local bacterial activity. Howeverer, during the latter stage of biofilm development, the percentage of active bacteria decreases as abundance of total bacteria increase, probably because there are enough bacteria to ensure biofilm growth. Furthermore, biofilm development results from both bacterial multiplication and recruitment of foreign bacteria which are not necessarily active but nonetheless increase total bacterial abundance (e.g. Bott \& Brock 1970, Costerton et al. 1987).

Consistent with the findings of Bärlocher \& Murdoch (1989) for biofilms developed on glass beads for 8 weeks, few significant correlations were observed between bacterial numbers and DOC concentrations, despite the nutritional dependence of hyporheic bacteria on dissolved substances in the water. After 3 days of colonization, total bacterial abundances were not correlated to nutrient content because nutrient concentrations never limited biofilm development. Instead, abundances may be determined by mobility of surrounding bacteria and colonization rate. In contrast, 
Day 3
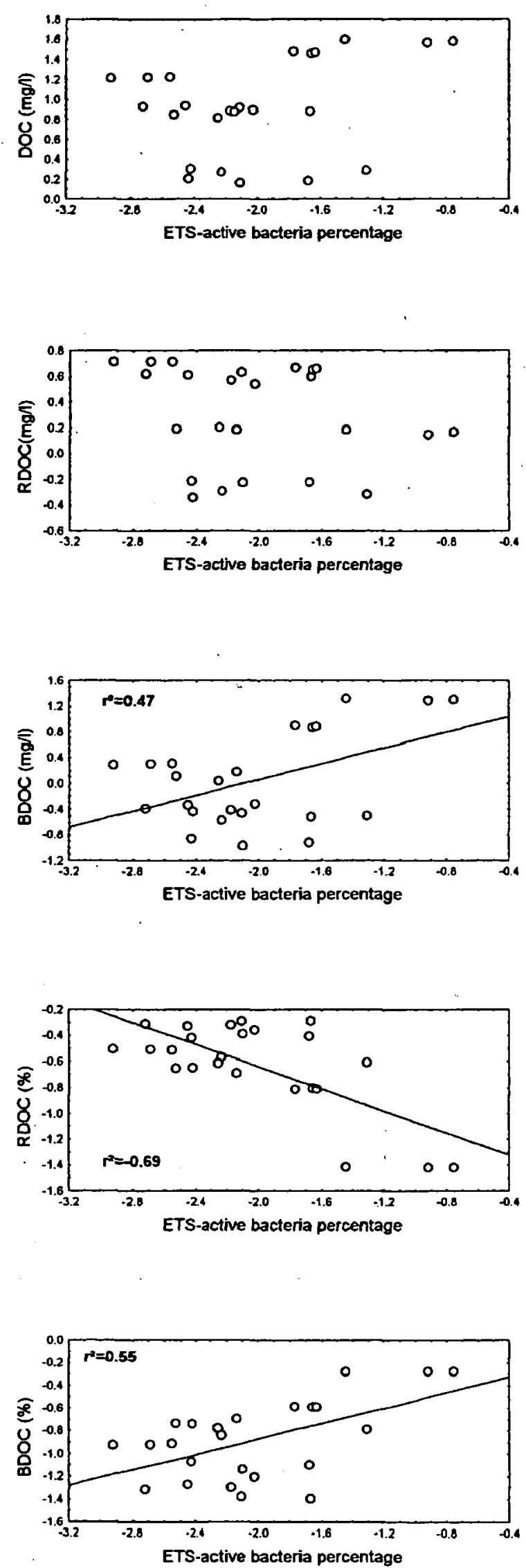

Day 7
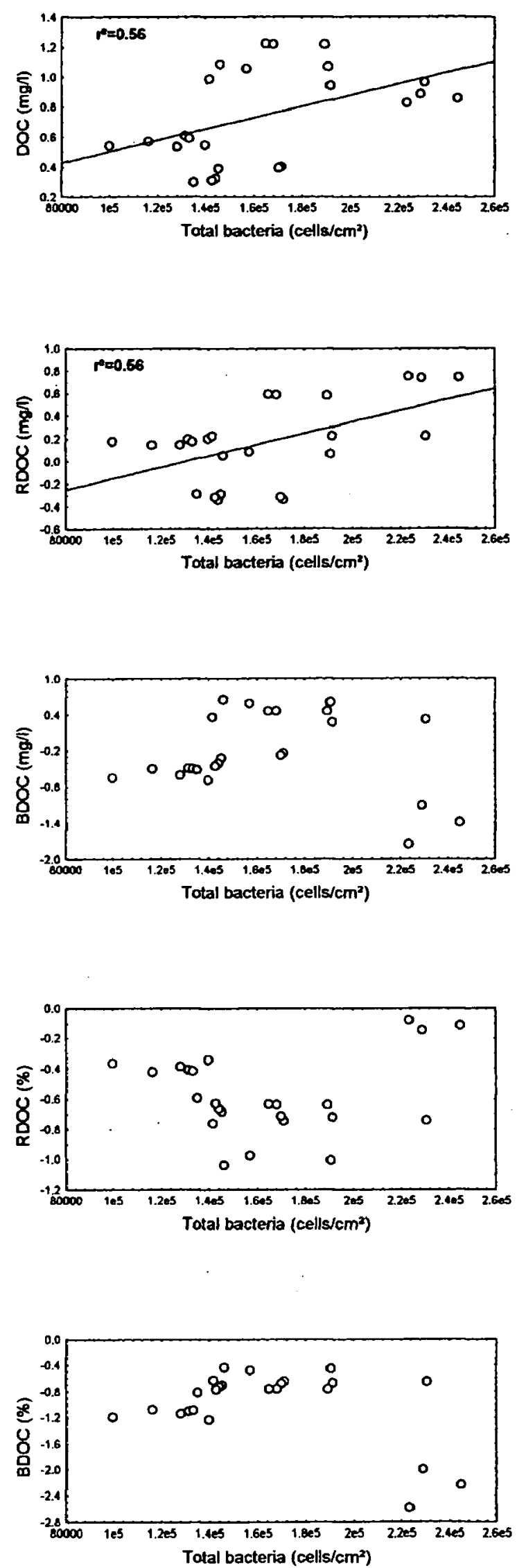

Fig. 3. Pearson's correlation (a) between DOC concentrations, BDOC and RDOC (concentrations and percentages) and ETS-active bacteria (\%) after 3 day exposure time, and (b) between DOC concentrations, BDOC and RDOC (concentrations and percentages) and Total bacterial abundances after 7 day exposure time. DOC concentration, BDOC, RDOC and ETS-active bacteria percentage have been [log (x)] transformed.

Fig. 3. Corrélations de Pearson (a) entre les concentrations en COD, CODB et CODR (concentrations et pourcentages) et les bactéries à STE-actif $(\%)$ après 3 jours d'incubation dans le milieu, et (b) entre les concentrations en COD, CODB et CODR (concentrations et pourcentages) et les abondances totales de bactéries après 7 jours d'incubation dans le milieu. Les concentrations en COD, CODB, CODR et le pourcentage de bactéries à STE -actif ont été transformés en $\log (\mathrm{x})$. 
percent ETS-active bacteria was correlated with percent of both BDOC and RDOC, suggesting that ETSactive bacteria were controlled by DOC that is, ETSactive bacteria (abundances and percentages) were enhanced by a high BDOC/DOC ratio, while a high RDOC/DOC ratio limited biofilm ETS activity.

After 7 days of exposure when the biofilm is more developed, DOC concentrations seem to become a limiting factor which controlled total bacterial abundance (Bott et al. 1984, Findlay \& Meyer 1984, Findlay et al. 1993, Sobczak 1996), as is suggested by the positive relationship between abundance of total bacteria and DOC concentration. This result is in disagreement with other studies that have shown that diffusion within biofilms decreases with increasing biofilm thickness (Lock 1981, Siegrist \& Gujer 1985, Peterson \& Grimm 1992). During development, biofilm becomes progressively more independent from available nutrients. Mulholland et al. (1981), noted that under nutrient-limited conditions, a thin biofilm primarily uses nutrients from the water column whereas a mature biofilm should rely on internally recycled nutrients. This logic suggests that hyporheic biofilms are thin and lack diffusion barriers, even after 7 days of incubation. Finally, the surprising positive correlation between bacterial abundance and RDOC concentration could be a result of the release of biofilm exudates, which are likely dominated by high molecular weight compounds that are difficult for bacteria to metabolize.

Two major conclusions can be drawn from this study: i) measurements of DOC and total bacterial abundance alone are not sufficient to understand trophic relationships in natural environment. These variables. should be complemented by the determination of BDOC and RDOC concentrations (measured by the Servais et al. 1987, 1989 method), and the identification of the proportion of the bacterial population that is actively respiring (measured with the CTC method). This set of parameters provides useful information on relationships between biofilm development and organic nutrients ; ii) total bacteria and ETS-active bacteria abundances that develop on artificial substrata during short exposure times could be simple, global parameters that provide information on functional linkages between biofilms and biodegradable and refractory fractions of DOC. However, biofilm colonization occurs in several stages due to organismal responses not only to nutrient availability, but also to physical factors (temperature, flow velocity ; Stock \& Ward 1989) and herbivore densities (Mulholland et al. 1991). Future research should include more information on the trophic context, along with a consideration of a wide range of abiotic and biotic variables, collected with standard methods (such as carbohydrates, $\mathrm{H}^{3}$-leucine and $\mathrm{H}^{3}$ thymidine incorporation and extracellular enzymatic activities) before this integrative biological tool can be used routinely for the evaluation of trophic status of aquatic systems.

\footnotetext{
Aknowledgments

This work was supported by grants from the Agence de l'Eau Rhône-Méditerranée-Corse. I would like to thank J.-N. Avrillier, G. Fauvet (Université de Savoie), and F. Mermillod-Blondin (Université Lyon I) for their help in the field, X. Gayte and P. Marmonier for their help in the field and valuable remarks on the manuscript, and Dr E. Stanley (Oklohoma State University, USA) for editing the english text.
}

\section{References}

Aloi J.E. 1990. - A critical review of recent freshwater periphyton field methods. Can. J. Fish. Aquat. Sci., 47 : 656-670.

Bakke R., Characklis W.G., Turakhia M.H. \& Yeh A.-I. 1990. Modelling a monopopulation biofilm system : Pseudomonas aeruginosa. In Biofilms. W.G. Characklis \& K.C. Marshall (eds.). John Wiley \& Sons Inc., New York : 487-520.

Bärlocher F. \& Murdoch J.H. 1989. - Hyporheic biofilms - a potential food source for interstitial animals. Hydrobiologia, 184 61-67.

Belkhadir R., Capdeville B. \& Roques H. 1988. - Etude descriptive fondamentale et modélisation de la croissance d'un film biologique - I. Etude descriptive fondamentale de la croissance d'un film biologique. Wat. Res., $22: 59-69$.

Boissier J.-M. \& Fontvieille D. 1992. - Biodegradable dissolved organic carbon in seepage waters from two forest soils. Soil Biol. Bioch., 25 : 1257-1261.

Bott T.L. \& Brock T.D. 1970. - Growth and metabolism of periphytic bacteria : methodology. Limnol. Oceanogr., 15 : 333-342.

Bott T.L., Brock J.T. \& Kuserk F.T. 1984. - Benthic bacterial biomass supported by stream water dissolved organic matter. Microb. Ecol., $10: 335-344$.

Capdeville B., Belkhadir R. \& Roques H. 1988. - Etude descriptive fondamentale de la croissance d'un film biologique - II. Nouveau concept de modélisation de la croissance d'un film biologique. Wat. Res., $22: 71-77$.

Cattaneo A. \& Amireault M.- C. 1992. - How artificial are artificial substrata for periphyton? J. N. Am. Benthol. Soc., 11: 244-256.

Characklis W.G., Trulear M.G., Bryers J.D. \& Zelver N. 1982. Dynamics of biofilm processes: methods. Wat. Res., $16: 1207$ 1215.

Claret C. 1998. - A method based on artificial substrates to monitor hyporheic biofilm development. Int. Revue ges. Hydrobiol., in press.

Claret C. \& Fontvieille D. 1997. - Characteristics of biofilm assemblages in two contrasted hydrodynamic and trophic contexts Microb. Ecol, $34:$ 49-57.

Costerton J.W., Cheng K.J., Gesey G.G., Ladd T.I., Nickel J.C., Dasgupta M. \& Marrie T.J. 1987. - Bacterial biofilms in nature and disease. Ann. Rev. Microb., 41 : 435-464.

Fiebig D.M. \& Lock M.A., 1991. — Immobilization of dissolved organic matter from groundwater discharging through the stream bed. Freshwater Biol., $26: 45-55$.

Fiebig D.M. 1992. - Fates of dissolved free amino acids in groundwater discharged through stream bed sediments. Hydrobiologia 235/236: 311-319. 
Findlay S. \& Meyer J.L. 1984. - Significance of bacterial biomass and production as an organic carbon source in lotic detrital systems. Bull. Mar. Sci., 35 : 318-325.

Findlay S., Howe K. \& Fontvieille D. 1993. - Bacterial-algal relationships in streams of the Hubbard Brook experimental forest. Ecology, 748 : 2326-2336.

Flemming H.-C. 1995. - Sorption sites in biofilms. Wat. Sci. Tech., $32: 27-33$.

Freeman C., Chapman P.J., Gilman K., Lock M.A., Reynolds B. \& Wheater H.S. 1995. - Ion exchange mechanisms and entrapment of nutrients by river biofilms. Hydrobiologia, $297: 61-65$.

Freeze R.A. \& Cherry J.A. 1979. - Groundwater. Prentice-Hall, Inc. Englewood Cliffs, New Jersey.

Fry J. C. 1988. - Determination of biomass. In Methods in aquatic bacteriology. B. Austin (ed.), J. Wiley \& Sons Ltd., New-York : 27-72.

Gibert J., Stanford J.A., Dole-Olivier M.-J. \& Ward J.V. 1994. Basic attributes of groundwater ecosystems and prospects for research. In Groundwater Ecology. Gibert J., Danielopol D.L. \& Stanford J.A. (eds.), Academic Press, San Diego, USA : 7-40.

Hoppe H.-G. 1991. - Microbial extracellular enzyme activity : a new key parameter in aquatic ecology. In Microbial Enzymes in Aquatic Environments. Chróst R.J. (ed.), Springer-Verlag, NewYork : 60-83

Jones S.E. \& Lock M.A. 1989. - Hydrolytic extracellular enzyme activity in heterotrophic biofilms from two contrasting streams. Freshwater Biol., 22 : 289-296.

Kevern N. R., Wilhm J.L. \& Van Dyne G.M. 1966. - Use of artificial substrata to estimate the productivity of periphyton. Limnol. Oceanogr., $11: 499-502$.

Kuroda M., Yuzawa M., Sakakibara Y. \& Okamura M. 1988. - Methanogenic bacteria adhered to solid supports. Wat. Res., 225 : 653-656.

Liu D., Lau Y.L., Chau Y.K. \& Pacepavicius G.J. 1993. — Characterization of biofilm development on artificial substratum in natural water. Wat. Res., $273: 361-367$.

Lock M.A. 1981. - River epilithon - a light and organic energy transducer: In Perspectives in Running Water Ecology. Lock M.A. \& Williams D.D. (eds.), Plenum Press, New York : 3-40.

Mickelburg. S., Lock M.A. \& Ford T.E. 1984. - Spatial uptake of dissolved organic.carbon in river beds. Hydrobiologia, 108 : 115119.
Mulholland P.J., Steinman A.D., Palumbo A.V. \& Elwood J.W. 1991. - Role of nutrient cycling and herbivory in regulating periphyton communities in laboratory streams. Ecology, 72:966-982.

Peterson C.G. \& Grimm N.B. 1992. - Temporal variation in enrichment effects during periphyton succession in a nitrogen-limited desert stream ecosystem. J. N. Am. Benthol. Soc., 11 : 20-36.

Rodriguez G.G., Phipps D., Ishiguro K. \& Ridgway H.F. 1992. Use of a fluorescent redox probe for direct visualization of actively respiring bacteria. Appl. Envir. Microbiol., 58 : 1801-1808.

Sabater S. \& Romani A.M. 1996. - Metabolic changes associated with biofilm formation in an undisturbed Mediterranean stream. Hydrobiologia, 335 : 107-113.

Schaule G., Flemming H.C. \& Ridgway H.F. 1993. - Use of 5-cyano-2,3-ditolyl tetrazolium chloride for quantifying planktonic and sessile respiring bacteria in drinking water. Appl. Envir. Microbiol., 59: 3850-3857.

Servais P., Billen G. \& Hascoët H.C. 1987. — Determination of the biodegradable fraction of dissolved organic matter in waters. Wat Res., 21 : 445-450.

Servais P., Anzil A. \& Ventresque C. 1989. - Simple method for determination of biodegradable dissolved organic carbon in water Appl. Envir. Microbiol., 55: 2732-2734.

Siegrist H. \& Gujer W. 1985. - Mass transfer mechanisms in a heterotrophic biofilm. Wat. Res., $19: 1369-1378$.

Sládecková A. 1962. - Limnological investigation methods for the periphyton «Aufwuchs» community. Bot. Rev., 28 : 286-350.

Sobczak W.V. 1996. - Epilithic bacterial responses to variations in algal biomass and labile dissolved organic carbon during biofilm colonization. J. N. Am. Benthol. Soc., $15: 143-154$.

Stock M.S. \& Ward A.K. 1989. — Establishment of a bed-rock epilithic community in a small stream: microbial algal and bacterial. Metabolism and physical structure. Can. J. Fish. Aquat Sci., 46 : 1874-1883.

Thurman E.M. 1985. - Organic carbon in natural waters. Amount, origin and classification. In Organic Geochemistry of natural waters. Thurman E.M. (ed.), Martinus Nijhoff / Dr.W Junk Publishers : 5-110.

Watanabe T., Capblancq J. \& Dauta A. 1988. - Utilisation des bioessais in situ sur substrats artificiels pour caractériser la qualité des eaux de rivière à l'aide du périphyton. Annls Limnol., 242 : 111-125

Yu F.P. \& McFeters G.A. 1994. - Rapid in situ assessment of physiological activities in bacterial biofilms using fluorescent probes. J. Microbiol. Meth. 20 : 1-10. 